\begin{tabular}{c} 
Brazilian Journal \\
of Chemical \\
Engineering \\
\hline
\end{tabular}

ISSN 0104-6632

Printed in Brazil

www.abeq.org.br/bjche

Vol. 28, No. 03, pp. $373-380$, July - September, 2011

\title{
HIDE UNHAIRING AND CHARACTERIZATION OF COMMERCIAL ENZYMES USED IN LEATHER MANUFACTURE
}

\author{
A. Dettmer ${ }^{1 *}$, M. A. Z. Ayub ${ }^{2}$ and M. Gutterres ${ }^{1 *}$ \\ ${ }^{1}$ Chemical Engineering Department, Laboratory for Leather and Environmental Studies (LACOURO), \\ Phone: + (55) (51) 3308 3954, Fax: + (55) (51) 3308 3277, Federal University of Rio Grande do Sul, \\ Luiz Englert str., s/nº, 90.040-040, Porto Alegre - RS, Brazil. \\ E-mail: alinedet@enq.ufrgs.br, mariliz@enq.ufrgs.br \\ ${ }^{2}$ Food Science and Technology Institute, BiotecLab, Federal University of Rio Grande do Sul, \\ Av. Bento Gonçalves, 9500, P.O. Box 15090, 91570-901, Porto Alegre - RS, Brazil.
}

(Submitted: September 6, 2010 ; Revised: March 25, 2011 ; Accepted: April 2, 2011)

\begin{abstract}
The enzymatic treatment of hides in tannery processes is a promising technology. However, the reaction kinetics of commercial enzymes available to the leather industry are not fully understood and their activities have been mainly determined with model proteins such as casein as substrate, which are not of direct relevance for cattle hides. Therefore, it is important to determine their activities on collagen and keratin, the main proteins of skin, in order to use these enzymes in leather processing. This work describes the study of five proteases, used commercially in tanneries, to assess their ability to act upon collagen and keratin and to determine their unhairing. Results showed that all commercial enzymes tested had more activity on collagen than on keratin. Unhairing was also tested and four out of the five enzymes tested showed some unhairing activity. Optima of the temperature and $\mathrm{pH}$ of the enzymes were very similar for all five enzymes, with maximal activities around $55^{\circ} \mathrm{C}$ and $\mathrm{pH} 9$ to 12 , respectively.
\end{abstract}

Keywords: Unhairing; Commercial enzymes; Enzyme characterization; Leather tanning.

\section{INTRODUCTION}

The leather industry converts hide (putrescible) into commercial leather (non-putrescible) using large amounts of chemicals, generating an environmental impact. Leather processing involves a series of unit operations, of which the process of unhairing is the first major step in leather making. The pelt has to be freed from the epidermis and hair, including the hair roots, and the keratinous material filling the hair follicles, before proceeding to the next step, the tanning (Sivasubramanian et al. 2008). During the unhairing process, large quantities of water and toxic chemicals such as sulfide are employed, generating huge amounts of effluent that must be treated, as well as solid wastes, that could be reused or better treated to avoid soil and water contaminations (Zhi-Hua et al., 2009; Priya et al. 2008; Galarza et al., 2009).

Despite its high environmental impact, the leather industry is economically important in regions where tanneries are prevalent and, in 2008, 343 million pieces of leather were produced worldwide. In this context, Brazil is one of the world's largest leather producers, with a production of 44 million pieces in 2009 , representing $13 \%$ of the total global production (Brazilian Guide of Leather, 2010).

The application of biotechnology in leather manufacturing, with the replacement of chemicals by enzymes, is an alternative for the reduction of the environmental impact. Enzymes can be applied in different steps of the process, such as in soaking, liming, unhairing, bating, dyeing, and degreasing, as

*To whom correspondence should be addressed 
well as for effluent treatment, both solid and liquid (Kanth et al., 2009; Kanth et al., 2008; Macedo et al., 2005; Dayanandan et al., 2003; Lutckmeier et al., 2008; Kumar et al., 2008). Despite being consolidated in other industrial applications, the use of enzymes in the leather industry needs more research to be effectively used in large scale operations and at competitive costs. Enzymes have been used in tanning industries for several years, but the majority of enzymatic preparations do not present sufficient specificity. Some of the expected advantages of using enzymes in leather processing are a shorter wetting time, better fiber opening, and solubilization and removal of proteins, fat and carbohydrates (Thanikaivelan et al., 2004). Enzymes could also be used for the unhairing process, epidermis and hair removal, removal of residual components, removal/dispersion of adipose components, and reduction of effluent load (Wang et al., 2009).

The currently marketed enzymes lack sufficient specificity and their characteristics are not well established in detail. Usually, their activities are determined using casein as substrate (BASF, 1995), while cattle hides do not have this protein in their composition. Therefore, it is important to establish their activities on collagen, the main component of animal skin, and keratin in order to allow their use in leather processing.

In this work, commercial enzymes available for the soaking, liming, and bating processes were characterized for their optimal $\mathrm{pH}$, temperature, thermal stability, and the influence of inhibitors. Furthermore, due to the possibility of eliminating the use of lime and sulfide, these commercial enzymes were also tested in the hide unhairing process.

\section{MATERIALS AND METHODS}

\section{Chemicals}

Five commercial protease preparations were used in this research and, for simplicity, they were identified as "A" to "E". Enzymes A (Buzyme 7703, Buckman Laboratories), B, and C (Tanzyme RD 04 and CD 05, respectively, both provided by Tanquímica) are unspecified preparations of microbial proteolytic enzymes, recommended for soaking and liming by their producers. Enzyme D (Tanzyme P 10, from Tanquímica), is a trypsin, while enzyme E (Buzyme 7706, from Buckman Laboratories) is a preparation of proteolytic enzymes. They are both applied during the bating process. The substrates for the enzymes used in his work were azocasein, keratin azure, and azocoll, bought from Sigma-Aldrich. All other reagents were of analytical grade.

\section{Proteolytic Assay}

Proteolysis using azocasein as substrate was based on Giongo et al. (2007). Enzymatic solutions were prepared immediately before their use, with concentrations of $5 \mathrm{mg}$ of commercial enzyme $/ \mathrm{ml}$ of distilled water. The reaction mixture contained $100 \mu \mathrm{l}$ of substrate (azocasein $10 \mathrm{mg} / \mathrm{ml}$ ), $100 \mu \mathrm{l}$ of buffer $(0.1 \mathrm{M}$ sodium bicarbonate or sodium phosphate, according to the $\mathrm{pH}$ value), and $100 \mu \mathrm{l}$ of enzyme solution (5 $\mathrm{mg}$ of enzyme/ml of distilled water). Samples were incubated at $37^{\circ} \mathrm{C}$ for $30 \mathrm{~min}$, and the reaction was stopped using $500 \mu \mathrm{l}$ of $10 \%$ trichloroacetic acid (TCA). After centrifugation at $10,000 \mathrm{~g}$ for $5 \mathrm{~min}, 800 \mu \mathrm{l}$ of the supernatant were added to $200 \mu \mathrm{l}$ of $1.8 \mathrm{~N} \mathrm{NaOH}$ and the absorbance was determined at $420 \mathrm{~nm}$. One unit of enzyme activity was defined as the amount of enzyme causing a change of absorbance of 0.01 at $420 \mathrm{~nm}$ in $30 \mathrm{~min}$ at $37^{\circ} \mathrm{C}$. Reaction controls were prepared by adding the enzyme solution, buffer and substrate solution to TCA.

\section{Keratinolytic and Collagenolytic Assay}

Enzymatic activities on keratin and collagen were determined using keratin azure and azocoll as substrates, respectively. The methodology was adapted from Adigüzel et al. (2009) and Ionata et al. (2008).

Keratinolytic activity was determined by incubating $500 \mu \mathrm{l}$ of enzyme solution with $4 \mathrm{mg}$ of keratin azure and $500 \mu \mathrm{l}$ of buffer $(0.1 \mathrm{M}$ sodium bicarbonate or sodium phosphate, according to the $\mathrm{pH}$ value). The reaction mixture was incubated at $55^{\circ} \mathrm{C}$ for $30 \mathrm{~min}$ under agitation. After centrifugation at $10,000 \mathrm{~g}$ for $5 \mathrm{~min}$, the absorbance was determined at $595 \mathrm{~nm}$. One unit of enzyme activity was defined as the amount of enzyme causing a change of absorbance of 0.01 at $595 \mathrm{~nm}$ in $30 \mathrm{~min}$ at $55^{\circ} \mathrm{C}$. The control was prepared by adding enzymatic solution and buffer, without substrate. The same procedure was used to evaluate enzymatic activity for azocoll.

\section{Effects of pH and Temperature on Enzymatic Activities}

The enzymes were characterized for their optimum $\mathrm{pH}$, temperature, and thermal stability, using azocasein as substrate. The activities were evaluated in $0.1 \mathrm{M}$ sodium phosphate $(\mathrm{pH} 6-8)$ or in $0.1 \mathrm{M}$ sodium bicarbonate $(\mathrm{pH} 9-13)$ buffers at $37^{\circ} \mathrm{C}$. The effect of temperature on enzymatic activities was tested between 28 and $75^{\circ} \mathrm{C}$, with the $\mathrm{pH}$ fixed at its best value, previously determined. The thermal stability of the enzymes was determined at their optimal $\mathrm{pH}$, with enzymatic solutions being exposed to temperatures of 37,45 , and $55^{\circ} \mathrm{C}$ for 15 , 
30, 60, and $120 \mathrm{~min}$. The residual enzymatic activities were determined as described above at $37^{\circ} \mathrm{C}$ and using azocasein as substrate.

\section{Effect of Inhibitors and Some Chemical Products on the Enzymatic Activity}

The effects of some chemicals on the activities of enzymes were tested. The chemicals were: $5 \mathrm{mM}$ EDTA; $0.1 \%$ (w/v) surfactant (Eusapon, Basf); $0.1 \%$ (v/v) fatty alcohols (Busperse 7769, Buckman Laboratories); salts $(0.5$ and $1 \% \mathrm{w} / \mathrm{v}$ calcium carbonate; $0.3 \% \quad \mathrm{w} / \mathrm{v}$ sodium carbonate); and $1 \%$ (w/v)sulfides; which are normally used during the leather production process. Although $\mathrm{CaCO}_{3}$ is insoluble at these concentrations, it were used to follow the practice by the leather industry, since the excess of this salt provides for skin saturation. Enzymatic solutions $(50 \mathrm{ml}$ of $5 \mathrm{mg}$ enzyme $/ \mathrm{ml}$ of distilled water) were preincubated for $15 \mathrm{~min}$ at room temperature with the tested chemicals at room temperature. The residual enzymatic activities were determined as described above at $37^{\circ} \mathrm{C}$ using azocasein as substrate.

\section{Unhairing Activity}

Bovine skin pieces weighing approximately $40 \mathrm{~g}$ were immersed in the enzyme solution $(5 \mathrm{mg}$ of commercial enzyme $/ \mathrm{ml}$ of distilled water, $\mathrm{pH} 8$ ) and incubated for $18 \mathrm{~h}$ at room temperature. About $2 \mathrm{ml}$ of enzyme solution $/ \mathrm{g}$ of hide were used for these experiments. The tests were conducted in a laboratory cylindrical drum rotating reactor (which is used for hide and leather processing) at $24 \mathrm{rpm}$. The next day, the pieces were analyzed for the presence or absence of depilated areas and change of color after incubation with the enzymatic solution.

\section{RESULTS AND DISCUSSION}

\section{Effects of $\mathrm{pH}$ and Temperature on the Proteolytic Activities}

The effects of $\mathrm{pH}$ on the enzymatic activities of the five commercial enzymes are shown in Figure 1 (a). As can be seen, proteolytic activities varied markedly from enzyme to enzyme but, in general, they followed the expected profile suggested by their producers. Enzymes A, B, and C are recommended to be used in the soaking and liming processes, where the usual $\mathrm{pH}$ ranges from 7.0 to 13.0. While Enzymes $\mathrm{D}$ and $\mathrm{E}$ are recommended for the bating process, in which the $\mathrm{pH}$ varies between 7.5 and 10 . Almost all the tested enzymes showed a remarkable loss of activity at $\mathrm{pH}$ lower than 7 and higher than 13, showing a plateau of high activity for $\mathrm{pH}$ varying from 7 to 12. These plateaus suggest the presence of two or more isoforms of the enzymes with the same specific substrate activities, but dependent on $\mathrm{pH}$ variations. Mixtures of enzyme isoforms are common in commercial enzymatic preparations for technical applications such as in the leather industry. These preparations can be used over a large range of $\mathrm{pH}$, which is interesting from the industrial point of view.

The profile of the influence of temperature on proteolytic activities can be observed in Figure 1(b), with maximal activities around $55^{\circ} \mathrm{C}$ for enzymes $\mathrm{A}$, $\mathrm{B}$, and $\mathrm{C}$, while enzymes $\mathrm{D}$ and $\mathrm{E}$ showed their best activity at $37^{\circ} \mathrm{C}$. Enzymes used for the bating process (enzyme D) are from the pancreatic family, such as trypsin, explaining their typically lower activities at higher temperatures. Above $60^{\circ} \mathrm{C}$, all enzymes presented decreased activities. These temperature profiles are similar to those found by other authors. The enzyme described by Ionata $e t$ al. (2008) had optimal activity at $55^{\circ} \mathrm{C}$, while Farag and Hassan (2004) also reported the highest activities for a keratinase from Aspergillus oryzae at $55^{\circ} \mathrm{C}$.

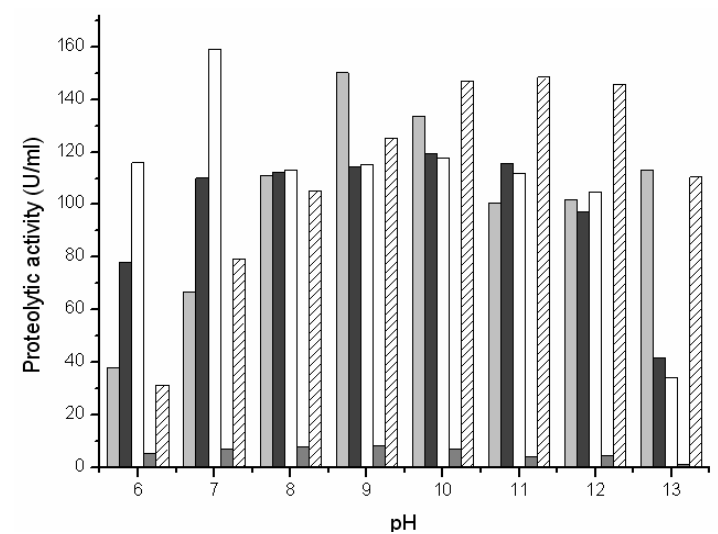

(a)

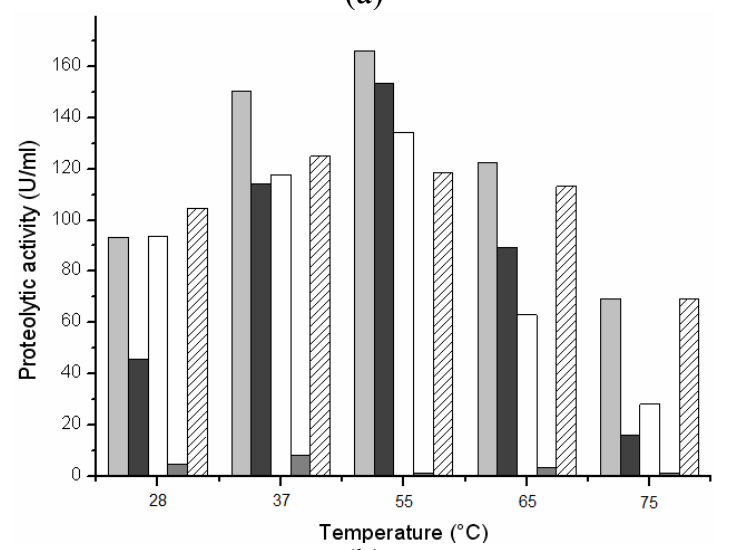

(b)

Figure 1: Effect of (a) $\mathrm{pH}$ and (b) temperature on the proteolytic activity, using azocasein as substrate.

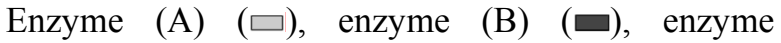

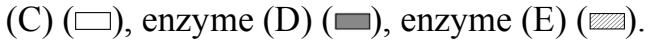




\section{Thermal Stability of Enzymes}

The thermal stability of enzymes is very important for their industrial utilization. In Figure 2, the thermal stability profiles of all enzymes tested are presented. Enzyme A was the most stable, maintaining its activity for 120 minutes at 37 and $45^{\circ} \mathrm{C}$, although even short times of incubation at $55^{\circ} \mathrm{C}$ were sufficient for its inactivation. The remaining enzymes were less stable

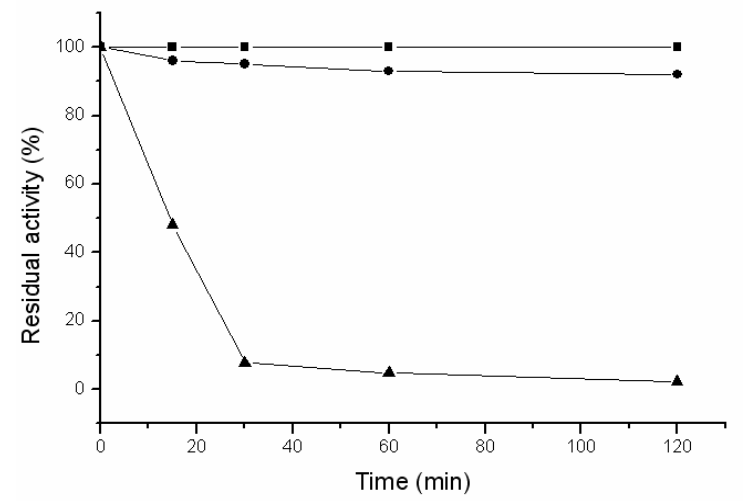

(a)

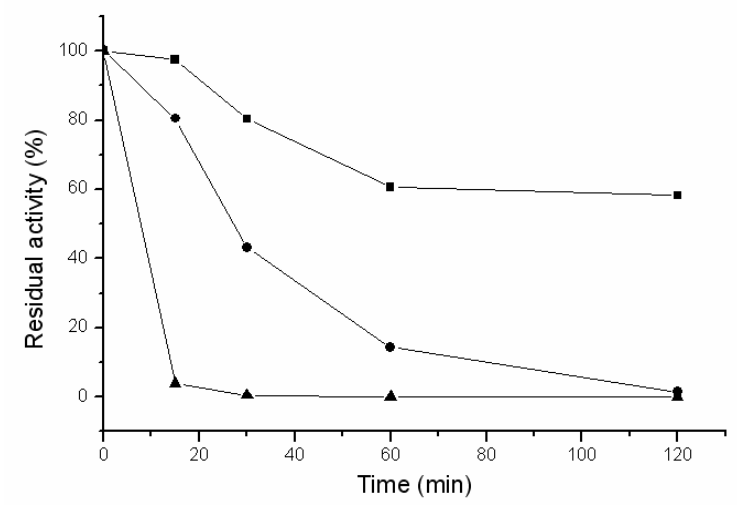

(c) at any tested temperature. Tatieni et al. (2008) reported that the activity of an enzyme from Streptomyces sp. was $80 \%$ stable at $50^{\circ} \mathrm{C}$ and completely inactivated at $70^{\circ} \mathrm{C}$ and higher temperatures. Ogino et al. (2008) evaluated the thermal stability of a Bacillus sp. enzyme. The authors found that the enzyme was stable from 30 to $40^{\circ} \mathrm{C}$ and about $60 \%$ of the activity remained at $50^{\circ} \mathrm{C}$, losing completely its activity above $60^{\circ} \mathrm{C}$ for $10 \mathrm{~min}$.

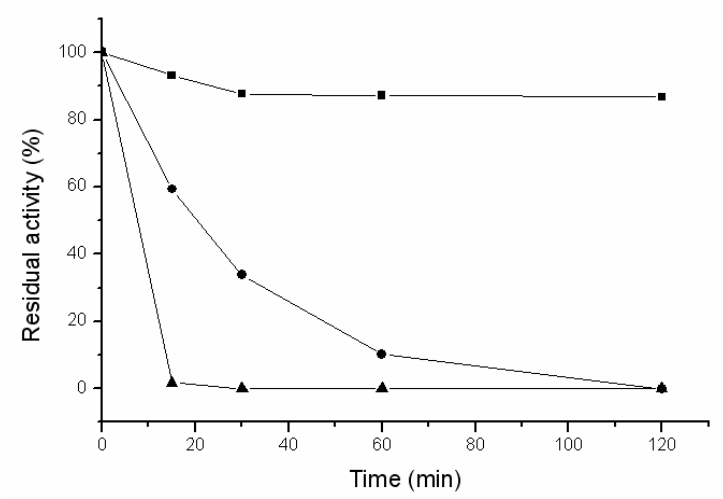

(b)

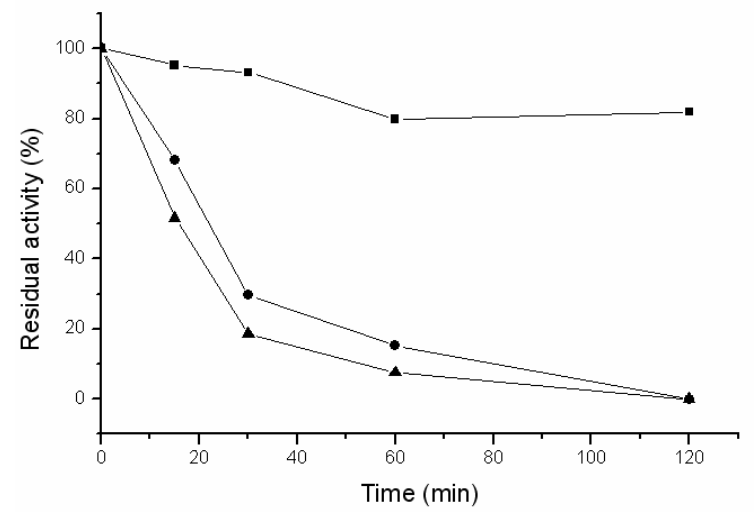

(d)

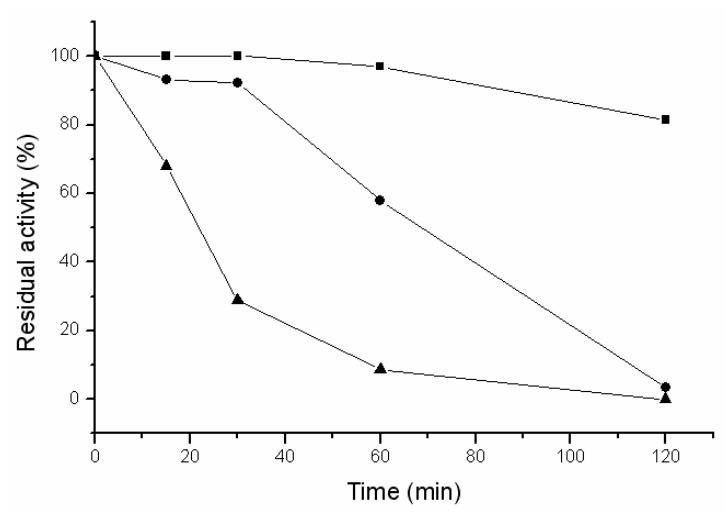

(e)

Figure 2: Thermal stability of protease preparations Enzyme A (a), Enzyme B (b), Enzyme C (c), Enzyme D (d) and Enzyme $\mathrm{E}(\mathrm{e}) .37^{\circ} \mathrm{C}(--), 45^{\circ} \mathrm{C}(-\bullet), \quad 55^{\circ} \mathrm{C}\left(-\bullet^{-}\right)$ 
Enzymatic Activities with Different Proteic Substrates: Azocoll, Keratin Azure, and Azocasein

Hides are mainly constituted of three layers: epidermis, which is basically keratin, dermis that is composed of collagen fibers, and hypodermis, mainly fat, which is completely removed during the fleshing process. Therefore, we carried out experiments by testing the activities of the 5 enzymes with different types of substrates, simulating different proteic structures. These were azocoll, keratin azure, and azocasein and the results are summarized in Table 1. Ratios between the activities for the different substrates are presented in Table 2.

Enzymes A, B, C and E exhibited the highest activities for azocasein, but were also active with the other substrates, keratin azure and azocoll. Keratin azure, which is an insoluble substrate, was less susceptible to enzymatic attack. According to Ionata et al. (2008), data from soluble proteins cannot be compared with those for insoluble proteins since the mechanism of action of enzymes on this substrate will be a function of the surface area. Enzyme A showed the highest activities among all enzymes tested, justifying its use in hide unhairing. However, its high activity with collagen (azocoll) might cause loss of skin mechanical strength and, therefore, its use must be carefully controlled. Keratinolytic proteases with mild collagenolytic and elastolytic activities might be particularly suitable for enhancing the dehairing process without harming the tensile strength of leather (Gupta and Ramnani, 2006). Results for collagenolytic activity suggest that enzymes A and E should be applied carefully, observing the time and amounts indicated in order to avoid loss of mechanical strength of the leather.

According to the ratios between keratin azure/azocasein and azocoll/azocasein, all 5 commercial enzymes can be classified as collagenolytic enzymes. All tested enzymes presented higher activities with collagen than with keratin, as can be seen in the results presented in Table 2. These results contrast with other reports, which presented higher ratios between keratin azure and azocasein than those for the commercial enzymes described in this work, as well as lower azocoll activities.

\section{Inhibitors of Enzymes Activities}

The salts and other chemicals present in industrial solutions may interfere with enzyme activity and therefore must be tested in order to prevent process losses. Table 3 presents the results of the effects of inhibitors and other chemical products on the enzymatic activities of the tested enzymes.

EDTA caused reductions of the activities of enzymes B and C, with little or no effect on enzymes A, $\mathrm{D}$, and $\mathrm{E}$. This might indicate the presence of metallic cations at the active centres of enzymes B and C, susceptible to EDTA sequestration (Kumar and Takagi, 1999). According to the manufactureres, enzymes B and $\mathrm{C}$ are non-specific preparations of microbial proteolytic enzymes, probably a mix of metalloproteases (inhibited by EDTA) and other proteases. These explain the residual activity of enzymes $\mathrm{A}, \mathrm{D}$ and $\mathrm{E}$ after contact with EDTA, because these enzymes may not be metalloproteases or may contain a minor fraction of metalloproteases. Tatineni et al. (2008) reported that a keratinase from Streptomyces sp. retains only $27 \%$ of its original activity after incubation with EDTA.

Fatty alcohol, which is an organic solvent, sodium carbonate, and the surfactant caused no significant variations in enzymes activities, except for enzyme D, which was more active in the presence of the surfactant, possible because this agent might have facilitated its action. Riffel et al. (2003) determined the residual activities of bacterial enzymes after incubation with organic solvents, the remaining activities being between 56 and $70 \%$. Enzyme D was completely inhibited when incubated with calcium carbonate. Enzymes B, C and D were inhibited by sodium sulfide, while enzyme A was activated by this chemical. Syed et al. (2009) reported that a keratinase from $S$. gulbargensis was totally inhibited by calcium compounds and its activity increased in the presence of sodium sulfite. Riffel et al. (2007) reported that a protease from Chryseobacterium sp. showed a 3.5 fold increase in its activity in the presence of calcium ions.

Table 1: Proteolytic activity with different substrates

\begin{tabular}{|c|c|c|c|c|c|}
\hline \multirow{3}{*}{ Substrate } & \multicolumn{5}{|c|}{ Enzymatic activity $(\mathrm{U} / \mathrm{ml})$} \\
\hline & \multicolumn{5}{|c|}{ Enzyme } \\
\hline & $\mathbf{A}$ & B & C & D & $\mathbf{E}$ \\
\hline Keratin azure & $25 \pm 1.98$ & $11 \pm 3.00$ & $12 \pm 0.2$ & $5 \pm 0.3$ & $13 \pm 1.76$ \\
\hline Azocoll & $110 \pm 0.85$ & $32 \pm 1.70$ & $25 \pm 5.2$ & $8 \pm 1.3$ & $76 \pm 0.6$ \\
\hline Azocasein & $166 \pm 3.96$ & $153 \pm 1.27$ & $134 \pm 2.1$ & $8 \pm 0.57$ & $145 \pm 1.91$ \\
\hline
\end{tabular}

Values are means \pm standard deviation for three samples. 
Table 2: Ratios between proteolytic activities for different substrates

\begin{tabular}{|l|c|c|c|c|c|c|c|c|}
\hline \multirow{3}{*}{ Substrate } & \multicolumn{8}{|c|}{ Ratios Between Proteolytic activities } \\
\cline { 2 - 9 } & \multicolumn{4}{|c|}{ Commercial Enzymes } & \multicolumn{4}{c|}{ Other Works } \\
\cline { 2 - 9 } & $\mathbf{A}$ & $\mathbf{B}$ & $\mathbf{C}$ & $\mathbf{D}$ & $\mathbf{E}$ & $\begin{array}{c}\text { Farag } \text { et. al. } \\
(\mathbf{2 0 0 4})\end{array}$ & $\begin{array}{c}\text { Pillai and } \\
\text { Archana (2008) }\end{array}$ & $\begin{array}{c}\text { Macedo } \text { et al. } \\
(\mathbf{2 0 0 8})\end{array}$ \\
\hline Keratin azure/ Azocasein Ratio & 0.15 & 0.07 & 0.09 & 0.63 & 0.09 & 0.92 & 0.94 & 0.012 \\
Azocoll/ Azocasein Ratio & 0.66 & 0.21 & 0.19 & 1.00 & 0.52 & 0.83 & 0.125 & 0 \\
\hline
\end{tabular}

Table 3: Effect of some inhibitors and chemical products on the enzymatic activity

\begin{tabular}{|c|c|c|c|c|c|c|}
\hline \multirow{3}{*}{ Chemical } & \multirow{3}{*}{ Concentration } & \multicolumn{5}{|c|}{ Residual Caseinolytic Activity (\%) } \\
\hline & & \multicolumn{5}{|c|}{ Enzyme } \\
\hline & & $\mathbf{A}$ & $\mathbf{B}$ & $\mathrm{C}$ & $\mathbf{D}$ & $\mathbf{E}$ \\
\hline EDTA & $5 \mathrm{mM}$ & $87 \pm 3.97$ & $33 \pm 1.70$ & $69 \pm 0.70$ & $87 \pm 0.70$ & $104 \pm 2.58$ \\
\hline Fatty alcohol (Busperse 7769) & $0.1 \%(\mathrm{v} / \mathrm{v})$ & $111 \pm 1.50$ & $96 \pm 1.60$ & $100 \pm 3.45$ & $85 \pm 0.76$ & $96 \pm 2.75$ \\
\hline Sodium carbonate & $0.3 \%(\mathrm{w} / \mathrm{v})$ & $103 \pm 0.20$ & $97 \pm 1.37$ & $97 \pm 3.97$ & $103 \pm 0.21$ & $98 \pm 2.90$ \\
\hline \multirow[t]{2}{*}{ Calcium carbonate } & $0.5 \%(\mathrm{w} / \mathrm{v})$ & $85 \pm 3.30$ & $107 \pm 4.33$ & $77 \pm 0.78$ & 0 & $83 \pm 0.68$ \\
\hline & $1 \%(\mathrm{w} / \mathrm{v})$ & $76 \pm 6.92$ & $113 \pm 13.71$ & $79 \pm 1.27$ & 0 & $85 \pm 8.76$ \\
\hline Surfactant (Eusapon) & $0.1 \%(\mathrm{w} / \mathrm{v})$ & $87 \pm 7.20$ & $92 \pm 1.77$ & $87 \pm 1.31$ & $161 \pm 1.60$ & $82 \pm 4.34$ \\
\hline Sodium sulfide & $1 \%(\mathrm{w} / \mathrm{v})$ & $138 \pm 2.57$ & $54 \pm 1.30$ & $57 \pm 3.97$ & $44 \pm 1.40$ & $75 \pm 0.75$ \\
\hline
\end{tabular}

Values are means \pm standard deviation for three samples.

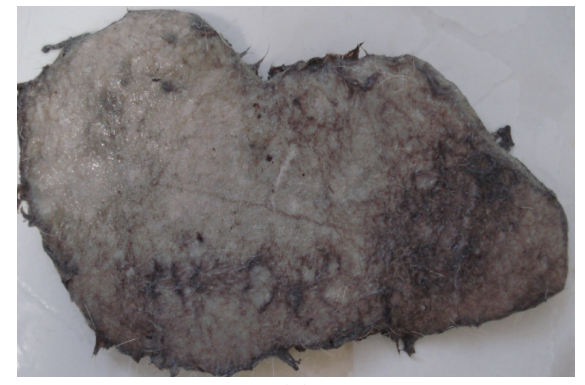

(a)

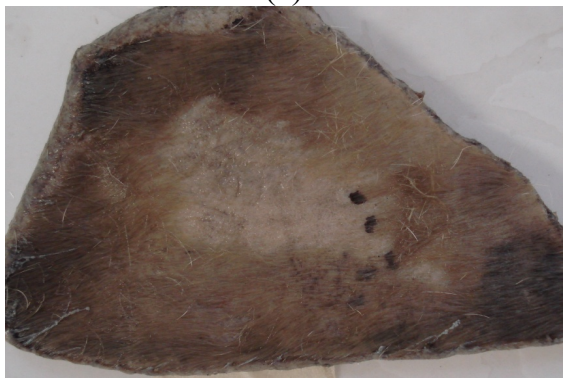

(d)

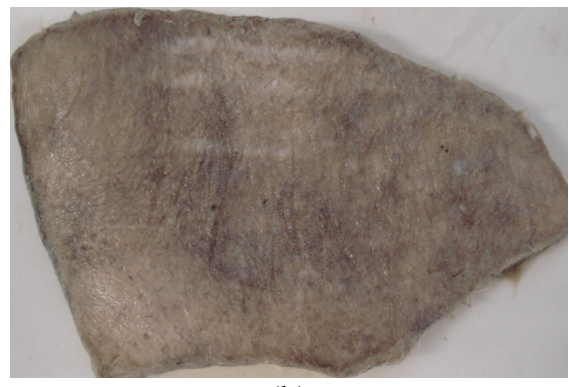

(b)

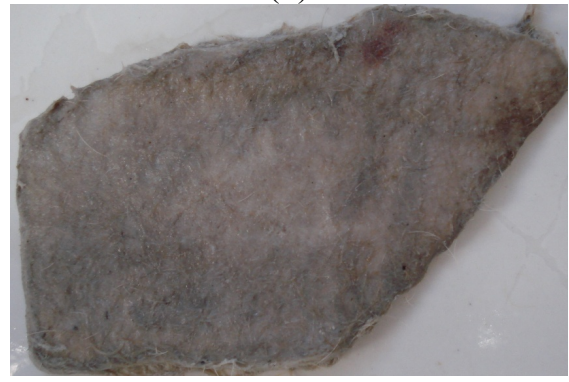

(e)

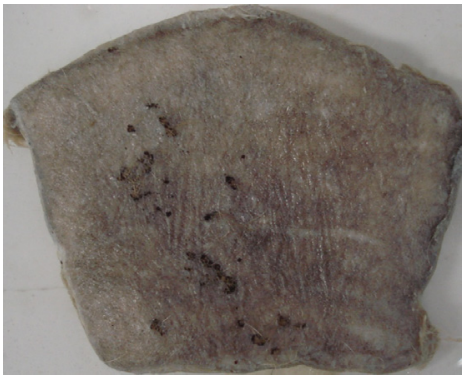

(c)

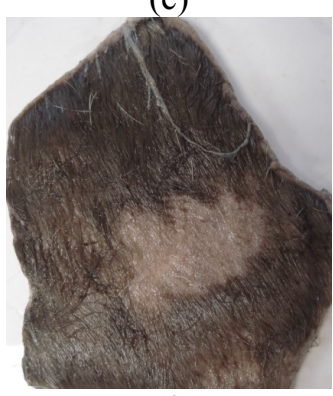

(f)

Figure 3: Hide unhairing tests. Enzyme A (a); Enzyme B (b); Enzyme C (c); Enzyme D (d); Enzyme E (e); Control, without enzyme (f). The unhaired box in the control was mechanically produced with a razor to serve as an area of reference.

\section{Enzyme Application for Leather Unhairing}

After these activity characterizations, the commercial enzymes were applied in the leather unhairing process to see whether their applications were promising. Figure 3 shows the results.

The enzymatic treatment of the hides produced significant differences compared to the control.
Hides treated with enzymes A, B, C, and E presented large depilated areas. These hides presented a dark coloration, caused by the incomplete removal of epidermis and pigments. According to Priya et al. (2008), enzymatic processes are associated with problems such as high cost, potential hide damage, processing time, retention of 'fine' or 'short' hairs after depilation, improper removal of epidermis and 
pigments, and the inability to control the action of the enzyme on the desired reticular structure of the dermis. Enzyme D showed a weak activity on leather, probably due to its low proteolytic, colagenolytic, and keratynolitic activities. Galarza et al. (2009) reported that the use of proteolytic enzymes in the unhairing process causes the digestion of the cells in the Malpighi's layer, of the basal cells of the hair bulb, degrading the medulla, but not the cortex. The keratin in the cortex is called hard keratin, as opposed to the soft keratin that is found in the hair medulla. During enzymatic unhairing (or hair loosening) there is a partial or total destruction of the tissues sustaining the hairs, the components of the epidermis surrounding the follicle and the root sheats. These tissues contain few disulfide bonds compared with hard keratins. It can, therefore, be suggested that the commercial enzymes tested in this work presented some capability to digest the soft $\alpha$-keratin. Pillai and Archana (2008) reported that an enzymatic preparation from Bacillus subtilis was ineffective in the hydrolysis of native $\alpha$ keratin, while under similar conditions, the feather $\beta$ keratins were nearly completely degraded.

\section{CONCLUSIONS}

The results of this work may help to elucidate some of the properties of enzymes used or recommended for leather production, including the determination of the ideal $\mathrm{pH}$ and temperature at which the enzymes show the best stabilities and activities. Activities on different substrates were tested, showing that enzyme A could be efficiently used for leather unhairing due to its good activity on keratin azure and azocoll, with enzymes B, C, and E showing a somewhat smaller unhairing activity. The chemicals normally used during leather production did not inhibit most of the enzymes tested.

\section{ACKNOWLEDGEMENTS}

The authors wish to thank the Brazilian Agencies CNPq (CTAgro 40/2008) and CAPES for their financial support of this study and for scholarships for the first author.

\section{REFERENCES}

Adigüzel, A. C., Bitlisli, B. O., Yasa, I., Eriksen, N. T., Sequential secretion of collagenolytic, elastolytic and keratinolytic proteases in peptide-limited cultures of two Bacillus cereus strains isolated from wool. J. Appl. Microbiol., 107, 226-234 (2009).

BASF, Vademécum para el técnico em curtición. $3^{\mathrm{a}}$ Edición, revisada y ampliada, agosto (1995).

Brazilian Guide of Leather, ABQTIC (2010).

Dayanandan, A., Kanagaraj, J., Sounderraj, L., Govindaraju, R., Rajkumar, G. S., Application of an alkaline protease in leather processing: an ecofriendly approach. J. of Cleaner Production, 11, 533-536 (2003).

Farag, A. M., Hassan, M. A., Purification, characterization and immobilization of a keratinase from Aspergillus oryzae. Enzyme and Microbial Technology, 34, 85-93 (2004).

Galarza, B. C., Cavello, I., Greco, C. A., Hours, R., Schuldt, M. M., Cantera, C. S., Alternative Technologies for adding value to bovine hair waste. J. Soc. Leather Technol. Chem., 94, 26-32 (2009).

Giongo, J. L., Lucas, F. S., Casarin, F., Heeb, P., Brandelli, A., Keratinolytic proteases of Bacillus species isolated from the Amazon basin showing remarkable de-hairing activity. World J. Microbiol. Biotechnol., 23, 375-382 (2007).

Gupta, R., Ramnani, P., Microbial keratinases and their prospective applications: an overview. Appl. Microbiol Biotechnol, 70, 21-33 (2006).

Ionata, E., Canganella, F., Bianconi, G., Benno, Y., Sakamoto, M., Capasso, A., Rossi, M., La Cara, F., A novel keratinase from Clostridium sporogenes bv. pennavorans bv. nov. a thermotolerant organism isolated from solfatic muds. Microbiol. Research, 163, 105-112 (2008).

Kanth, S. V., Venba, R., Madhan, B., Chandrababu, N. K., Sadulla, S., Studies on the influence of bacterial collagenase in leather dyeing. Dyes and Pigments, 76, 338-347 (2008).

Kanth, S. V., Venba, R., Madhan, B., Chandrababu, N. K., Sadulla, S., Cleaner tanning practices for tannery pollution abatement: Role of enzymes in eco-friendly vegetable tanning. J. of Cleaner Production, 17, 507-515 (2009).

Kumar, A. G., Swarnalatha, S., Sairam, B., Sekaran, G., Production of alkaline protease by Pseudomonas aeruginosa using proteinaceous solid waste generated from leather manufacturing industries. Bioresource Technol, 99, 1939-1944 (2008).

Kumar, C. G., Takagi, H., Microbial alkaline proteases: from bioindustrial viewpoint. Biotechnol. Advances, 17, p. 561-594 (1999).

Lutckmeier, C., Amaral, L., Gutterres, M., Marcílio, N., Dechroming of wet-blue leather wastes, XVII FLAQTIC Congress, Rio de Janeiro (2008). 
Macedo, A. J., Silva, W. O. B., Gava, R., Driemeier, D., Henriques, J. A. P., Termignoni, C., Novel keratinase from Bacillus subtilus S14 exhibiting remarkable dehairing capabilities. Applied and Environmental Microbiol, 594-596 Jan. (2005).

Macedo, A. J., Silva, W. O. B., Termignoni, C., Proprieties of a non collagen-degrading Bacillus subtilis keratinase. Can. J. Microbiology, 54, 180188 (2008).

Ogino, H., Otsubo, T., Ishikawa H., Screening, purification and characterization of a leatherdegrading protease. Biochem. Engineering J., 38, p. 234-240 (2008).

Pillai, P., Archana, G., Hide depilation and feather disintegration studies with keratinolytic serine protease from a novel Bacillus subtilis isolate. Appl. Microbiol. Biotechnol., 78, 643-650 (2008).

Priya, S., Rajaram, A., Rajaram, R., Ramasami, T., Depilation of skins by pure enzymes. J. of the Society of Leather Technologists and Chemists, 92, 214-221 (2008).

Riffel, A., Lucas, F., Heeb, P., Brandelli, A., Characterization of a new keratinolytic bacterium that completely degrades native feather keratin. Arch. Microbiol., 179, 258-265 (2003).

Riffel, A., Brandelli, A., Bellato, C. M., Souza, G. H. M. F., Eberlin, M. N., Tavares, F. C. A., Purification and characterization of a keratinolytic metalloprotease from Chryseobacterium sp. kr6. J. of Biotechnol. 128, 693-703 (2007).

Sivasubramanian, S., Manohar, B. M., Rajaram, A., Puvanakrishnan, R., Ecofriendly lime and sulfide free enzymatic dehairing of skins and hides using a bacterial alkaline protease. Chemosphere, 70, 1015-1024 (2008).

Syed, D. G., Lee J. C., Li, W. J., Kim, C. J., Agasa, D., Production, characterization and application of keratinase from Streptomyces gulbargensis. Bioresource Technol., 100, 1868-1871 (2009).

Tatineni, R., Doddapaneni, K. K., Potumarthi, R. C., Vellanki, R. N., Kandathil, M. T., Kolli, N., Mangamoori, L. N., Purification and characterization of an alkaline keratinase from Streptomyces sp. Bioresource Technol., 99, 15961602 (2008).

Thanikaivelan, P., Rao, J. R., Nair B. U., Ramasami, T., Progress and recent trends in biotechnological methods for leather processing, Trends in Biotechnol., 22 (2004).

Zhi-Hua, S., Qing, L. S., Jian-Wei, L., Ollis, D. L., Lime-free removal of non-collagen proteins from sheepskins: quantitative analysis by gel electrophoresis. J. of the Society of Leather Technol. and Chem., 93, 229-232 (2009).

Wang, R., Min, C., Haiming, C., Li, Z., Enzyme unhairing - an eco-friendly biotechnological process. J. Soc. Leather Technol. Chem., 93, 51-55 (2009). 